\title{
Piracy in a Failed State: How State-Building Can Stabilize the Situation off the Somali Coast?
}

\author{
Akiko Sugiki *
}

The main purpose of this paper is to examine an alternative approach to statebuilding in Somalia to resolve issues regarding maritime piracy off the Somali coast. The sharp increase in piracy in Somalia is often regarded as a consequence of the collapse of the State after 1991. Solutions for curtailing piracy therefore depend upon the reconstruction of the State in Somalia. However, as has been the case in many post-conflict countries, Somalia has experienced a number of unsuccessful attempts at state-building because the current state-building model based on the western conception of statehood does not account for the realities of Somali society. Reviving a unified Somalia is thus counter-productive to securing peace, order and stability. By closely examining state-building approaches, this paper shows that the "mediated state' approach is the most appropriate model not only for resolving issues regarding state-building, but also for tackling the root causes of piracy in Somalia.

\section{Keywords}

Somalia, Piracy, State-Building, Failed State, Negotiating Statehood, Mediated State

\section{Introduction}

The dramatic upsurge in incidents of piracy off the Somali coast in recent years has posed significant challenges to maritime security in general, and international shipping and maritime trading in particular. Since 2008, multi-national organizations, such as the

* Associate Professor of International Relations at the Faculty of Law, Kobe Gakuin Univiersty. B.A.(Tsuda), LL.M.(Keio), M.Sc(LSE), M.A./Ph.D.(Essex). The author may be contacted at: asugiki@law.kobegakuin.ac.jp/Address: Faculty of Law, Kobe Gakuin University, 1-1-3 Minatojima, Chuo-ku, Kobe 650-0036 Japan. 
European Union ("EU") and the North Atlantic Treaty Organization ("NATO"), and various countries have dispatched warships to combat piracy. On February 1, 2009, finally, the Maritime Security Centre-Horn of Africa ("MSC-HOA") established the International Recommended Transit Corridor ("RTC"). According to the International Maritime Bureau ("IMB"), however, 47 of the 219 vessels attacked by pirates in 2009 were successfully hijacked. ${ }^{1}$ In comparison, 111 attacks were reported in 2008, which in turn represented a 200\% increase from 2007 levels. ${ }^{2}$ In 2010 and 2011, Somali pirates accounted for approximately $54 \%$ of the world's piracy; the overall number of Somali piracy incidents has continued to increase from 219 in 2010 to 237 in 2011, although the number of successful hijackings decreased from 49 to 28 over the same period. ${ }^{3}$ The strategy of using naval patrols in the Gulf of Aden and the Somali Basin has reduced the number of successful hijackings, but pirates have shifted their operations to attack vessels as far as 1200 nautical miles from the Somali coast (toward the western and southern coasts of India in the Indian Ocean). Further, pirates are also attacking vessels close to the coasts of Tanzania, Kenya, Somalia, and Yemen. In 2011, an anchored vessel was hijacked by Somali pirates within the territorial waters of Oman. 4 These hijacking cases indicate that Somali piracy cannot be successfully countered without addressing its root causes, because piracy is interrelated with the state of anarchy and lack of rule of law in Somalia. Thus, rebuilding the Somali state is considered crucial to solving the problem of piracy. 5 How to rebuild the Somali State remains a matter of debate, however. There are two major approaches to state-building: the 'top-down' approach and the 'bottom-up' or 'building-block' approach. The international community has attempted to (re)build so-called 'failed states' by employing the conventional top-down approach to state-building.

Since the fall of Siad Barre's regime in 1991, however, there has been no central government in operation; rather, Somalia has been divided into the three administratively- separate territorial entities: Somaliland, Puntland, and the South (See Map 1). The Transitional Federal Government ("TFG"), which is regarded as the "legitimate central government of Somalia," exercises no control over most regions of

1 ICC Commercial Crime Service, 2009 World Piracy Figures Surpass 400 (January 14, 2010), available at http://www.icc-ccs.org/news/385-2009-worldwide-piracy-figures-surpass-400 (last visited on Feb. 1, 2012).

2 ICC Commercial Crime Service, Piracy and Armed Robbery against Ships, Annual RePort 2008, available at http://ddata.over-blog.com/xxxyyy/0/50/29/09/Docs-Textes/Pirates2008RAP-BMI0901.pdf (last visited on Feb. 1, 2012).

3 ICC Commercial Crime Service, Piracy Attacks in East and West Africa Dominate World Report (January 19, 2012), available at http://www.icc-ccs.org/news/995-piracy-attacks-in-east-and-west-africa-dominate-world-report (last visited on Feb. 1, 2012).

4 Id.

5 Akiko Sugiki, Rethinking 'State-building' : Piracy Off the Coast of Somalia and Rebuilding 'Somalia,' 110 J. INT' L L. \& DIPL. 8 (2011) (「国家建設」モデルの再考序論一ソマリア沖海賊問題と「ソマリア国家」の事例から, 国際法 外交雑誌 第110号，2011年) (available only in Japanese). 
Somalia. The TFG's presence has been limited to a few city blocks of the capital Mogadishu. ${ }^{6}$ More than a dozen national peace conferences have discussed how to revive the Somali State, but none have achieved success. Most efforts have been hindered by internal actors who are reluctant to see the control of the State fall into the hands of rival clans or factions. External interventions and regional conflicts have also had a negative impact on Somalia. However, this does not mean all initiatives for rebuilding Somalia are doomed to fail. Rather, the failure of state-building efforts in Somalia lies in the type of state-building paradigms employed by external and internal actors in the country. Many Somali political leaders and external mediators have sought to reconstruct Somalia through the conventional notions of state-building, which emphasizes the strengthening of the central government. However, many academics and practitioners who have tracked Somalia for years hold that any solution to the problems in Somalia lies in the strategy known as a 'bottom-up' or 'building block' approach.7 Although Somalia is often pessimistically described as a 'failed state,' not all parts of the country lack governance. Somaliland and Puntland have functional local governing institutions, and maintain relative peace and stability as a result. In addition, not all parts of the Somalia are infected by piracy. Various studies indicate that the main pirate areas are located in central Somalia and Puntland. 8

\section{Map 1: Somali State Formation Process after 1991}

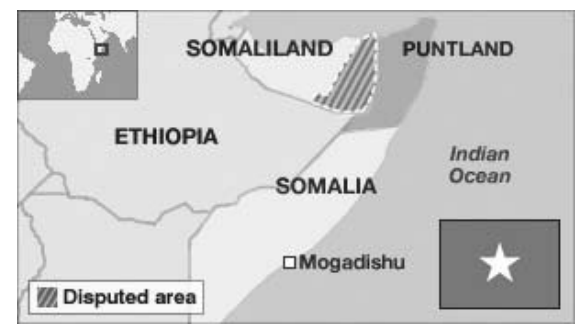

Source: BBC Somalia Profile (Feb. 10, 2012), available at http://www.bbc.co.uk/news/world-africa14094503 (last visited on Apr. 1, 2012)

6 International Crisis Group, Somalia: Transitional Government on Life Support, 170 AFRICA RePoRT 1 (February 21, 2011), available at http://www.crisisgroup.org/ /media/Files/africa/horn-of-africa/somalia/170\%20Somalia\%20 The\%20Transitional\%20Government\%20on\%20Life\%20Support.pdf (last visited on Feb. 1, 2012).

7 J. Peter Pham, Putting Somali Piracy in Context, in Somalia: STate Collapse, Terrorism and Piracy 88 (Briane Hesse ed. 2011).

8 See e.g. UN Security Council, Report of the Monitoring Group on Somalia pursuant to Security Council Resolution 1811 (December 10, 2008), S/2008/769, available at: http://www.unhcr.org/refworld/docid/494900240.html; Report of the Monitoring Group on Somalia pursuant to Security Council Resolution 1853(2008), S/2010/91, 38 (2010), available at http://reliefweb.int/sites/reliefweb.int/files/resources/467A5CB05AD7E446492576EA0004325DFull_Report.pdf (all last visited on Feb. 1, 2012). 
This paper will investigate the validity of the 'mediated state' approach proposed by Kenneth Menkhaus as an alternative method for dealing with the issue of piracy in Somalia. ${ }^{9}$ According to Menkhaus's approach, a State with unstable central government relies on a diverse range of local authorities to execute core government functions and 'mediate' the relationship between the central and local communities. In this case, the central government would not directly control the political and social spheres of all communities directly, but would exert influence through a process of mediation. 10 Although piracy is most active in Puntland, the region has modest functioning institutions. Thus, this paper examines whether support for local institutions in Puntland is relevant to resolving the root causes of piracy. This paper is divided into six parts including Introduction and Conclusion. Part II will examine two approaches to state-building and present the mediated states approach as a conceptual framework for reconstructing the Somali State and planning alternative counter-piracy policies. Part III will provide an overview of the background of Somali pirates. Part IV will investigate the relationship between the development of piracy and the political situation in Puntland. Part V will consider the relevance of the mediated state approach in terms of counter-piracy measures.

\section{State-Building in Somalia and the Mediated State Approach}

\section{A. Overview}

Somalia is often regarded as a typical 'collapsed state' or 'failed state.' Since 1991, no central government has been able to exert control over the whole territory of Somalia. Sporadic fighting has continued in several parts of the country. Also, numerous external initiatives for state-building have not been successful in rebuilding a unified Somali State.

State-building is an equivocal conception because the term 'State' is itself vague. The current arguments regarding state-building, however, can be divided into two approaches: the institutional approach and the legitimacy approach. The former focuses on reconstructing institutions of the State and strengthening its institutional capacity to

9 Kenneth Menkkaus, Somalia: Governance vs. Statebuilding, in Building States to Build Peace, 212-213 (C. Call \& V. Wyeth eds. 2008). 
provide public goods. 11 The latter approach recognizes the importance of State institutions, but emphasizes the complex nature of socio-political cohesion or what some refer to as nation-building. 12 Since the 1990s, the United Nations and other actors have attempted to rebuild the State based on the institutional approach to statebuilding. As Robert Rotberg argues, the international community regards the State as the foremost supplier of political goods, regardless of its origin, realities or appropriateness. 13 The current state-building initiative contains a wide array of projects such as Disarmament, Demobilization, Reintegration ("DDR"), the Security Sector Reform ("SSR"), and a variety of other efforts aimed at rebuilding political, economic and legal institutions, developing infrastructure, and promoting education, economic development, etc. All this assistance relates to a particular State model emphasizing the monopolization of the legitimate use of physical force within a given territory, as well as a political-economic system based on the principles of liberal democracy and free market.

However, the institutional approach to state-building has not been successful. For example, Monika François and Inder Sud investigated seven countries in which the UN has undertaken state-building project since 1989. Their research reveals that only four countries out of the seven have maintained peace, and only three of those have established a democratic political system. 14 Similarly, Roland Paris points out that among eleven UN peace-building operations launched between 1989 and 1998, only two missions (Namibia and Croatia) were successful.15 These results were a product of various factors related to institutional approaches to state-building. Here, the author will point out three major problems with the approach, all of which have strong implications for state-building in Somalia.

First, external actors design the state-building project under the top-down decisionmaking process without carefully considering local situations. The most important policies are determined in international conferences that largely reflect donors' interests. As a result, local people tend to see state-building assistance as illegitimate and refuse to accept it. Although international actors have advocated the importance of ownership, local representation or participation in the decision-making process has generally

11 Charles T. Call, Ending Wars,in Building States in Building States to Build Peace 5 (C. Call \& V. Wyeth eds. 2008).

12 Nicolas Lemay-Hébert, Statebuilding without Nation-Building? Legitimacy, State Failure and the Limits of the Institutional Approach, 3 J. INTERVENTION \& STATEBUILDING 22 (2009).

13 Robert Rotberg, The Failure and Collapse of Nation-States: Breakdown, Prevention and Repair, in WHEN STATES FAIL: CAUSES AND CONSEQUENCES 28 (R. Rotberg ed. 2004).

14 Monika François and Inder Sud, Promoting Stability and Development in Fragile and Failed States, 24 Dev. PoL'y REV. 150-151 (2006).

15 Ronald Paris, At War’s End: Bullding Peace After Civil Conflict 58-62 (2004). 
become a ritual devoid of substance. 16

Second, the institutional approach is premised on the monopolization of the use of force and the establishment of a liberal political and economic system. Two important criticisms can be made here. The first is the appropriateness of a liberal political system. The international community intends to introduce liberal democracy and a free market economy to post-conflict countries because this model is conceived as appropriate for preventing conflict from recurring. This idea can be found in numerous writings, including the liberal peace conception argued by Michael Doyle. ${ }^{17}$ However, numerous cases in sub-Sahara have shown that incorporating democracy and a market economy do not lead a country to restore peace and stability. For example, conflicts recurred in Angola and Sierra Leone after elections based on the multi-party system. The other is the fact that the dogmatic attachment to liberal democracy in state-building denies the possibility that may be suitable in some countries under certain circumstances. Tobias Hagmann and Markus Hoehne argue that the contemporary debates on state-building presume that all States will converge toward a model of western liberal democracy in the long run;18 this model has become the institutional guideline for state-building and the benchmark against which all existing forms of statehood are assessed. This 'state convergence' thesis is problematic because it denies the multiple processes of statebuilding and forms of statehood incompatible with the Western model, and ignores the existence (and importance) of multiple local governance systems both formal and informal. 19

The third problem with the institutional approach is that it ignores the question of legitimacy. Generally, state-building initiatives have taken place in post-colonial States that achieved independence from colonial rule after 1945. Most of those countries confronted double legitimacy crises. The first legitimacy question is territorial boundaries. Most post-colonial States inherited administrative units from the former colonial governments. These units were often arbitrarily constructed as a result of negotiations or wars between colonial powers. Generally, these geographical divisions did not correspond to the will or interest of local people. Under the "divide and rule" strategy, most colonial governments created preferential policies for a specific national or ethnic group: a system that invoked resentment and confrontation among ethnic

\footnotetext{
16 Louise Andersen, What to Do? The Dilemmas of International Engagement in Fragile States, in FraGiLe STATES AND Insecure People? : Violence, Security, ANd STAtehood in the Twenty-First Century 30 (Louise Anderson et al. eds. 2007).

17 Michel Doyle, Kant, Liberal Legacies and Foreign Affairs, 12 PhILosophy \& PUB. Affairs 205-235 (1983); Kant, Liberal Legacies and Foreign Affairs, Part 2, 12 PHILosophy \& PuB. AFF. 323-353 (1983).

18 Tobias Hagmann \& Markus V. Hoehne, Failures of the State Failure Debate: Evidence from the Somali Territories, 21 J. INT'L DEV. 43-54 (2009).

19 Id.
} 
groups by design. Although the various independence movements against the colonial government have played a certain role in uniting people under colonial rule, this did not necessarily lead all post-colonial nations to create a national consciousness or a strong sense of solidarity cutting across all ethnic groups. 20 The other legitimacy issue is the relationship between civil society and government. As David Roberts illustrates, ruling elites in post-colonial countries have pursued their vested interests through elite patronage and clientelism while suppressing those who oppose their regimes.21 Thus, most people began to mistrust and disrespect the State's ruling elites and government; they were highly skeptical about the legitimacy of State institutions. Chandler argues that it is inappropriate for external actors to rebuild a State without popular support and legitimacy, since this will result in a weak State having little connection with its national society. It also lacks legitimate authority.22

\section{B. Negotiating Statehood and State-Building}

There is no magic formula for reconstructing a State that obtains legitimacy for people who reside in the territory, largely because there are so few successful state-building cases to learn from. It is also difficult to identify the factors that facilitate the evolution from failed State to functional State. However, from the historical state-building process in Europe or Japan, a certain consensus about state-building has emerged. As Charles Tilly argues, war makes States and State makes war. ${ }^{23}$ State-building in the Western world has been a long process that has been advanced by many types of confrontations, such as wars and negotiations among various social actors. ${ }^{24}$ Recently, special attention has been given to the negotiations between actors in post-colonial States, leading academics such as O. Richmond or Shahar Hameiri to develop some new approached to state-building. ${ }^{25}$ In this paper, the author will use one of these new approaches - namely the

20 Donald Horowitz, Ethnic Groups in Conflict 3-12 (1985). See also Masahisa KaWabata, African Renaissance 115117 (2003).

21 David Roberts, Post-Conflict Statebuilding and State Legitimacy: From Negative to Positive Peace?, 39 Dev. ChangE 541-45 (2008).

22 David Chandler, International State-Building: Beyond Conditionality, Beyond Sovereignty, Guest Seminar, Royal Institute for International Relations (IRRI-KIIB) 12 (2005), available at http://www.davidchandler.org/pdf/papers/ Beyond\%20Conditionality\%20Beyond\%20Sovereignty.pdf (last visited on Nov. 10, 2011).

23 Charles Tilly, War Making and State Making as Organized Crime, in Bringing the STATE BaCk In 169-186 (Peter Evans ed. 1985).

24 Zoe Scott, Literature Review on State-Building 9-10 (2007), available at http://www.gsdrc.org/docs/open/HD528.pdf (last visited on Nov. 10, 2011).

25 See Oliver Richmond, A Genealogy of Peace and Conflict Theory, in Palgrave Advances in Peacekeeping: Critical Developments and Approaches 26-35 (Oliver Richmond ed. 2010); Shahar Hmeiri, Regulating Statehood: State Building AND The TRansformation of THE GLOBAL ORDER 10-63 (2010). 
"negotiating statehood framework" proposed by Hagmann and Péclard - to reconsider state-building in Somalia. Hagmann and Péclard suggest that statehood is forged through the dynamic and partly undetermined process of negotiation among local, national and international actors. ${ }^{26}$ In this process, the list of actors involved in the negotiation of statehood is not limited to government officials, political elites, and military leaders, but also includes various social groups from the wider society, such as the customs authorities, trade unions, civil society organizations, warlords, big men, businessmen, multinational corporations, and regional and international organizations. Those actors negotiate political identity, authority structures, and the redistribution of resources in 'negotiation arenas' and at the 'negotiation table' through the use of their 'resources' and 'repertoires.' Consequently, state-building and formation are inherently conflictive and contested; they are subject to institutional transformation. 27

The negotiating statehood framework contains three main advantages. First, since this framework focuses on what States are and do - what the author will call 'empirical statehood' - it provides a useful insight for understanding an alternative arrangement of governance or regulating mechanism when the State has collapsed. For instance, in the Butembo region of the eastern Democratic Republic of Congo, the negotiations between local businessmen and the armed group, the Rassemblement Congolais pour la Démocratie-Mouvement de Libération ("RCD-ML") led to a system of alternative governance, or 'no-state governance.' 28 Second, this framework provides a crucial perspective for examining the complicated links between various actors. Third, this conception assumes the dynamic and at least partly undermined processes of statebuilding. In this process, State institutions are not definitively formed, but constantly changed and reformed. 29

\section{State-Building in Somalia}

This section considers the state-building process in Somalia following the negotiating statehood framework. Since 1991, both internal actors (warlords based on clan or subclan, militias Islamist organizations) and external actors have played significant role in conflicts of Somalia. 30 The author will examine the major negotiation processes

26 Tobias Hagmann \& Didier Péclard, Negotiating Statehood: Dynamics of Power and Domination in Africa, 41 DEv. CHANGE 539-57 (2010).

$27 \quad I d$.

28 Timothy Raeymaekers, Protection for Sale? War and the Transformation of Regulation on the Congo-Ugandan Border, 41 Dev. Change 563-587 (2010).

29 Sugiki, Supra note 5, at 82-85.

30 Endo Mitsugi, Somalia ni okeru 'funso' to sono gendaiteki kadai ソマリアにおける「紛争」とその現代的課題 (Conflicts in Somalia and its Agenda), 57 KaIGAIJJyo 海外事情 (KNowledge of Foreign Affairs) 2-17 (2009). 
regarding statehood that have taken place at the national and regional levels.

\section{National Level: Peace Process and the TFG}

Negotiations among various actors at the national level have taken place at more than twenty-one peace and reconciliation conferences held in the post-Barre years. Thus far, the most important conferences are the Arta process established in Djibouti (1999 to 2000), the Nairobi conference in Kenya (October 2002 to October 2004) and the Djibouti peace process (2008 to 2009). ${ }^{31}$ All three have tried to create a unitary State.

The Arta process was the most grassroots-based conference, encompassing more than 3,000 civil society members, traditional leaders, intellectuals, and businessmen, as well as warlords. The conference elected 900 delegates who were later appointed members of the Transitional National Assembly ("TNA") for three years. There, Addullah Ahmed Addow was elected president of the Transitional National Government ("TNG").32 Since its beginning, however, the TNG encountered numerous problems. Prominent warlords, such as Hussein Aideed and Muhammad Sa' id Hirsi 'Morgan,' refused to accept the authority of the TNG and blocked its activities. Ethiopia also rejected the result of the Arta process, because Ethiopia's government feared the influence of Islamic fundamentalists. Ethiopia's government hindered the TNG by supporting the Somalia Reconciliation and Restoration Committee formed by anti-TNG factions and groups. As a result, Somalia was divided into two factions; ongoing confrontation between the two sides led to the TNG's dysfunction. 33

To break the impasse, the Intergovernmental Authority on Development ("IGAD") sponsored the Nairobi conference, hosted by the Kenyan government from October 2002 to October 2004. After lengthy discussions and negations, a Transitional Federal Charter ("TFC") was adopted in February 2004. Then, the 27-member Transitional Federal Parliament ("TFP") was selected. In October 2004, the TFP elected Abdullahi Yusuf Ahmed president of the TFG. The TFG was formed under the 4.5 formula, which allocated an equal number of places to each of the four major clan families (Hawiye, Darod, Digil-Rahanweyn, and Dir) and a half-place to the minority clans. Ethiopia took the initiative at the Nairobi process. In particular, Ethiopia rewarded the warlords who supported its policies by appointing them members of the TFP and the cabinet. However, members of civil society, nationalist intellectuals, Islamists and those who did not cooperate with Ethiopia were excluded from the peace process. Since Ethiopia and

\footnotetext{
31 Apuuli Kasaija, The UN-led Djibouti Peace Process for Somalia, in Somalia: State CollaPse, Terrorism and PiRacy 13-30 (Brian Hasse ed. 2011).

32 Stig Hansen, Warlords and Peace Strategies: The Case of Somalia, 23 Conflict STUD. $65-66$ (2003).

33 Kasaija, supra note 31 , at 16 .
} 
Kenya, along with the IGAD arbitrarily selected most members of the TFP, they alienated internal and external actors important to the restoration peace in Somalia. ${ }^{34}$ The TFG's crucial posts - namely the president, prime minister and the major ministers in the cabinet - were dominated by pro-Ethiopian politicians, most of which were from the Majeerteen of Darod clan. ${ }^{35}$ As the TFG was regarded as a puppet government of Ethiopia, many Somalis questioned the TFG's legitimacy. The result was a weak government with constant infighting and little public support. In March 2005, less than a year after the TFG's inception, the government had splintered into two groups: one led by President Yusuf and the other, the 'Mogadishu group,' composed of parliamentarians and warlords mainly based in the capital and principally from the Hawiye clan. 36

When the TFG, like its predecessor, fell short of imposing any form of order, security or State functionality, the Union of Islamic Courts ("UIC") emerged in Somalia in the first half of 2006. By June 2006, the UIC had managed to gain control of Mogadishu by defeating and neutralizing the warlords there and extended its control to most of the southern and central parts of Somalia by August 2006. The UIC was regarded as a strong alternative to the TFG because the UIC delivered a high level of security and public services to the population. Fearing Islamic radicalism and the Greater Somalia policy, Ethiopia launched a military intervention on Christmas Eve of 2006. Ethiopian forces defeated the UIC rather quickly and captured Mogadishu on December 28, 2008. The TFG, which had hitherto been situated in Baidoa, entered Mogadishu. However, inviting Ethiopian forces into Somalia further fueled mistrust and hostility against the TFG. The TFG eventually failed to establish its authority over the country. 37

After being defeated in January 2007, the former leaders of the UIC regrouped and formed the Alliance for the Re-liberation of Somalia ("ARS") in September 2007. In addition, Al-Shabaab, a group of hardcore Islamist fighters (formerly the military wing of the UIC) emerged and extended its influence over southern Somalia. As a result, fighting and clashes between clans and armed groups intensified, causing a serious humanitarian crisis. 38

Ahmedou Ould Abudullah, who was appointed the United Nations special representative to Somalia, coordinated the peace conference in Djibouti under the

34 Afyare Abdi Elmi, Understanding the Somalia Conflagration: Identity, Political Islam and Peacebuiding 23-26 (2010).

35 However, it must be noted that Prime Minister Ali Mohamed Gedi is from Abgal of Hawiye clan.

36 Kasaija, supra note 31 , at 17.

37 Endo, supra note 30, at 10-16.

38 International Crisis Group, Somalia: To Move Beyond the Failed State, 147 Crisis Group RePort 10 (December 23, 2008), available at http://www.observatori.org/paises/pais_74/documentos/147_somalia_to_move_beyond_ the_failed_state.pdf (last visited on Feb. 1, 2012). 
auspices of the UN in 2008. In this process, Prime Minister Nur Hassan Hussein played a significant role in the negotiations between the TFG and the ARS. These negotiations invoked an internal dispute in the ARS, which was divided into two factions: ARSDjibouti ("ARS-D") led by the moderate Sheikh Sharif Ahmed; and ARS-Asmara("ARSA") led by the hardliner Hassan Dahir 'Aweys.' At the same time, the relationship between President Yusuf and Prime Minister Hussan Hussein became strained. President Yusuf was finally forced to resign as the main external actors, including the IGAD, the African Union ("AU") and the UN Security Council, all supported Hussan.39 In November 2008, the TFG and the ARS-D reached a power-sharing agreement. The main contents of this agreement are as follows: the establishment of a unity government and an inclusive parliament, with extra 200 seats allocated to the ARS and seventy-five additional seats for members of civil society and the diaspora. 40 The transitional period was also extended for two years. In January 2009, Sheikh Sharif was elected president of the TFG, and Omar Abdirashid Sharmarke was selected as prime minister.

However, this peace process is hardly inclusive, because the ARS-A, Al-Shabaab and other Islamic militant groups refused to participate in the peace process. Al-Shabaab and Hizbul Islam have increased their military attacks against the TFG; the TFG's survival depends entirely on the African Union Mission in Somalia ("AMISOM") and the support of the international community. When Sheikh Sharif became president, he pledged to create an administration that would advance good governance and clean up the corruption. However, the current government has been incapable of delivering on his promise. The majority of Somalis have become disillusioned with the TFG in general and with President Sharif in particular. Given the internal and external conditions, it is unlikely the TFG will be able to expand its authority over all of Somalia.41

\section{Negotiation at the Regional Level: the Case of Puntland}

In 1998, some 1.5 million Somalis in northeast Somalia declared themselves to be an autonomous Puntland State of Somalia. Puntland is sometimes called the 'Darod Project' or 'Darod homeland,' as the majority of Puntland's population is Harti, a subclan of the Darod clan. 42

Following the outbreak and intensification of conflict in southern Somalia after 1991, the Darod clan elders held a conference and adopted the Garowe Declaration, which

\footnotetext{
39 Kasaija, supra note 31, at 26-30.

40 Decisions of the High Level Committee Djibouti Agreement (Nov. 25, 2008) 9 4, available at http://www.hdcentre.org/ files/26\%20November\%20Communique.pdf (last visited on Feb. 1, 2012).

41 Sugiki, supra note 5, at 2-15.

42 International Crisis Group, Somalia: The Trouble with Puntland, 64 AfriCA BRIEFING 2 (Aug. 12, 2009), available at http://www.somaliawatch.org/archivejun09/090815601.pdf (last visited on Feb. 1, 2012).
} 
established a regional administration in 1998. The creation of Puntland was closely associated with the Somali Salvation Democratic Front ("SSDF"), which had initially been organized as a Darod-clan guerrilla movement against the Barre regime. As a close ally of Ethiopia and recipient of its financial and military assistance, the SSDF fought the radical Islamist movement al-Ittihad al-Islami ("AIAI") in 1992. After the Garowe Declaration, a 66-member unicameral parliament was established, and the SSDF leader, Abdullahi Yusuf Ahmed, was selected as a caretaker president for three years. In 1999, the Puntland Charter was adopted, and a relatively more efficient tax and revenue collection system was introduced. Courts and prisons were reconstructed in major towns. Initially, Puntland consolidated its image as a functional regional State. Indeed, Puntland was a successful example of the building block approach or bottom-up approach to state-building. 43

\section{Factors Challenging the State-Building of Somalia at the National Level}

Although the negotiations regarding statehood have taken place at the national and regional levels, they failed to construct a unitary Somali State. At the risk of oversimplification, two domestic and two external challenges can be identified as a continuing significantly to the continued failure of state-building in Somalia. The main domestic challenges are clan affiliation (or clanism) and the presence of radical Islamist movements. Historically, Somali society is lineage-based, a genealogical system in which almost everyone is identified by his or her clan membership. Clan affiliation has been deeply incorporated into Somali social and political institutions, and influences a variety of social realms such as personal identity, customary law (xeer), blood payment (diya) groups and social support systems. Clans are a crucial source of individual and family security, functioning as an insurance system in times of violence or danger. Clan identity itself is not a direct cause of conflict, but clan membership has been mobilized in crises and has repeatedly undermined state-building efforts. 44 Menkhaus explains why the attempt to revive a functional State in Somalia has encouraged violence and ended up in the zero-sum game. He argues that the Somali State has historically been the principal source of power and wealth for clans and coalitions thereof. The repressive and predatory feature of the Barre regime led Somalis to distrust and doubt the State as an institution. Thus, although many Somalis understand the advantages of a functional central government, they cannot accept that the State may be controlled by rival clans or factions. Since 1991, therefore, attempts to reconstruct a central government have been

\footnotetext{
43 See Matt Bryden, New Hope for Somalia? The Building Block Approach, 26 Rev. Afr. PoL. Eco'y 134-140 (1999); S. Hansen, Warlords and Peace Strategies, 23 J. Conflict STUd. 57-58 (2003).

44 Elmi, supra note 34 , at 35.
} 
conceived as a zero-sum game by Somali actors; they have just triggered deadly conflicts. 45

With regard to Islamic values and movements, there are two different views about the role of Islam in Somali state-building. Many people believe that an Islamic identity has a better chance of functioning as an inclusive one for reconstruction. 46 Somalis are regarded as being about 99\% Sunni Muslim. ${ }^{47}$ Except for their Islamic identity, there is no inclusive identity that can encompass clan identity and create a Somali national identity. 48

In the political realm, Islam as experienced in Somalia is not similar to Islam elsewhere; Sufi tariquas (brotherhoods) have tended to avoid involvement in the country's politics, (although one of the main sects, the Shlihiya, was the brotherhood of Said Mohamed Abdullah). In the past, Islam was mobilized only to resist British and Italian colonial rule. 49 There are several versions of the origins of political Islam or Islamic awakening in Somalia. However, most Muslims agree that Sheik Mohamed Moallim Hassan became the patriarch of the Islamic awakening in Somalia when he came back from Egypt in 1969.50 His teaching had so a great impact on the youth at that time that he was widely respected by various groups. In the early 1970s, Sheikh Mohamed Moallim organized the first coherent Islamic movement in Somali, the AlAhili. Fearing the Islamic influence, the Barre regime occasionally cracked down on them. In particular, in 1975, Sheik Mohamed Moallim and many other scholars were arrested, causing several clashes between Muslims and security forces. Opinion was divided among Islamic groups about the use of force to influence politics.51 The AI-Ahili movement divided into two groups, Jama' a Islmiya and Islah. As time passed, more splinter groups emerged, although almost all Muslims in Somalia used non-violent methods before 1991. A new phenomenon has emerged since the collapse of the Barre regime, the outbreak of civil war, and the beginning of the AIAI's military operations. Although the AIAI's influence declined by around 2005, new militant Islamist groups, such as Al-Shabaab and Hizbul Islam, have emerged. Until August 2011, Al-Shabaab controlled most of southern and central Somalia. Most Somalis have not been ardent

Supra note 9, at 202-203. See also the same author, Governance without Government in Somalia, 31 INT' L SECURITY 74-106 (2006/7).

46 Elimi, supra note 34 , at 140.

47 Maria Barons, Society, Security, Sovereignty and the State in Somalia: From Statelessness to Statelessness? 95 (2001).

48 Elmi, supra note 34 at 28-72.

49 In Somalia, generally there are three prominent Sufi tariquas (brotherhoods): the Qadiriya, the Ahmadiya, and an Ahmadiya derivative, the Shlihiya. Said Mohamed Abdullah and his dervish followers have fought against Britain, France, Italy and Ethiopia since 1899. See Barons, supra note 46, at 96.

50 Elimi, supra note 34 , at 57-58.

51 Id. at 59. 
supporters of Al-Shabaab, which has imposed strict sharia law and banned humanitarian assistance from external actors. Somalis accept Al-Shabaab's rule because the group has managed to sustain order and security. ${ }^{52}$ Most Somalis are devout, but moderate in the practice of their faith. However, the secular regime has not been able to protect people's interests and needs. As the secular State failed to sustain order and stability, Islamic movements became an alternative.

Political and/or military interference by external actors, especially Ethiopia and the United States, has undermined peace and state-building in Somalia. Ethiopia has sustained a hostile relationship with Somalia for hundreds of years. Ethiopian policies toward Somalia have shared two main considerations: religious extremism (i.e., Islamist movements) and Greater Somalia or Pan-Somali nationalism.53 It is often believed that Ethiopia has attempted to establish a weak, friendly and divided Somali government that would not threaten Ethiopia's security and national interests. Since 1991, Ethiopia has been both political and military involved in Somalia's internal affairs, which in turn has prolonged the conflicts. ${ }^{54}$ The United States has been very reluctant to engage in Somalia after the end of United Nations Operation in Somalia ("UNOSOM II") in 1995.55 Since September 11, 2001, however, Washington has regarded Somalia as the third front on its "war on terror" and has therefore supported Ethiopia and its allied warlords. Washington rarely carries out military operations directly, though it was heavily involved in removing the UIC from power in December 2006.56

Another crucial regional actor, Kenya, has also followed Ethiopia's policy. However, until October 2011, Kenya has generally avoided direct military intervention in Somalia except for the military campaign against the UIC in late 2006 and early 2007. In addition, due to a hostile relationship with Ethiopia, Eritrea has provided political and military assistance to armed groups, warlords and Islamist groups that oppose Ethiopia. Among regional organizations, the Arab League and the Organization of Islamic States have not been actively involved in Somalia for the last twenty years. However, the AU and the IGAD have been heavily involved in the Somali conflict. 57

M. Bøås and N. Rotwitt, Remaking the Somali State: A Renewed Building-block Approach, in NoREF REPORT (September 2010), available at http://www.peacebuilding.no/var/ezflow_site/storage/original/application/ 1350becf14cb330b38abd42904f80613.pdf (last visited on Feb. 1, 2012).

53 The Federal Democratic Republic of Ethiopia Foreign Affairs and National Security Policy and Strategy, Ethiopia's Policy Toward Somalia, available at http://www.mfa.gov.et/Foreign_Policy_And_Relation/Relations_With_Horn_ Africa_Somalia.php (last visited on Oct. 10, 2011).

54 Elmi, supra note 34, at 90-96.

55 See United Nations Operation in Somalia II, available at http://www.un.org/Depts/DPKO/Missions/unosom2b.htm (last visited on Feb. 1, 2012).

56 Elmi, supra note 34 , at 73-89.

57 Id. at $97-107$. 
Given these domestic and external factors that hinder state-building at the national level, and the rise of local, informal and self-autonomous polities, at least in the short run, it is unlikely that the TFG or another government could control the entire country. Instead, it seems that some form of a mediated state would be appropriate for statebuilding in Somalia. 58 In this model, a central government with very limited power relies on a diverse range of local authorities to execute the government's core functions and 'mediates' relations between local communities and the central government. 59 In fact, negotiations between domestic actors over the post-TFG arrangement would incorporate the idea of the mediated state approach into the future political system. Certainly, there are several problems with applying this model in Somalia for counterpiracy measures.

\section{The Background of Piracy off the Somali Coast}

There are numerous disagreements regarding the beginning of piracy in Somalia. ${ }^{60}$ It is generally accepted that piracy started in 1991. It was not until 2008, however, that the frequency of Somali piracy began to increase rapidly.61 Somali piracy can be divided into two types: defensive and predatory. The former relates to local fishermen; they claim they are defending their fishing grounds against illegal fishing. ${ }^{62}$ Toward the end of 2008, Somali pirates captured two vessels: the M/V Fina, a Ukrainian cargo vessel loaded with weapons and ammunition; and the M/V Sirius Star, a massive Saudi oil tanker. These two cases illustrate that Somali piracy is no longer carried out by small ragtag groups of Somali fishermen defending their fishing grounds. Rather, pirates groups are organized systematically and professionally by various actors, such as negotiators, spokesmen, accountants, financiers, logistic coordinators, and caretakers, as well as pirates. 63

58 Sugiki, supra note 5 , at 89 .

59 Supra note 9, at 190.

60 E.g., Ken Menkhaus maintains that Somali piracy begun in 1991, but Karl Sörenson argues that piracy started in 2003. See Ken Menkhaus, Dangerous Waters, 51 Survival: Global Politics \& STrategy 21-25 (2009); Karl Sörenson, State Failure on the High Seas: Reviewing the Somali Piracy, in FOI Somalia PAPERS: REPORT 3 (2008), available at http://www.foi.se/upload/projects/Africa/FOI-R-2610.pdf (last visited on Feb. 1, 2012).

61 From 1989 to 1991, the Somali National Movement ("SNM") hijacked ships and confiscated their goods. At that time, the SNM was fighting the Barre regime and justified their acts as a means of preventing weapons from reaching the government. These incidents occurred in a legal grey zone, but could be considered the first piracy incidents in Somalia.

62 Martin Murphy, Somalia: The New Barbary? Piracy and Islam in the Horn of Africa 17 (2011).

63 Patrick Lennox, Contemporary Piracy off the Horn of Africa, Canadian Defence and Foreign PoLICY INSTITUTE 
According to the report by the UN monitoring group on Somalia, there are two major pirate groups: one operates in central Somalia, and is comprised primarily of members of the Habar Gidir clan; and the other is based in Puntland, and consists mainly of members of the Majerteen clan. The most influential pirate groups operate in Eyl, while other groups are based in Gara' ad, Aluula, Haafun, Bossaso, Bayla, Bagal and Quandala.64 The pirate groups range from small groups (fathers and sons) to large organizations of 200 pirates or more. Most of these groups are organized around close family or village ties in a loose constellation under a pirate leader, usually a veteran pirate, who reinvests funds in new pirate missions and often functions as a fund-raiser. Established pirate leaders such as Garrad Mohamud Mohamed and Mohamed Abdi Hassan 'Afweyne' are well connected and respected in the local community. They can resolve problems and obtain personal protection through their personal networks. 65

The pirate attack groups generally consist of two or three skiffs, each manned by four to seven armed pirates and often deployed from a mother ship. In the past, pirate crews had to stay close to the Somali coast due to the limited amount of fuel and a lack of navigation equipment. 66 Mother ships have increased opportunities for operations at great distance from land and for longer periods at sea. Pirates are usually armed with assault rifles, such as the AK-47, as well as small weapons, including rocket-propelled grenade-7V launchers. Although pirates rarely harm or kill hostages, allegedly, they would not hesitate to use violence if they feel threatened or an attempt is made to retake the hijacked vessel and/or free the hostages. 67

Once the pirates seize a vessel, they generally demand that the crew take the hijacked ship to their favored port where the pirates' ground team can provide food/facilities and local protection while negotiation takes place over the ransom. Pirates initially contact and make demands of the owners or managers of the vessel; they often protract negotiations until both sides (pirates and owners) agree on the ransom amount.

As negotiations are a very important task in the pirate business, negotiators/

REPORT 10 (2008), available at http://www.cdfai.org/PDF/Contemporary\%20Piracy\%20off\%20the\%20Horn\%20of\% 20Africa.pdf (last visited on Feb. 1, 2012).

64 See Report of the Monitoring Group on Somalia pursuant to Security Council Resolution 1811, supra note 8, at 29; Lauren Ploch et al., Piracy off the Horn of Africa, Congressional Research Service 6 (April 19, 2010), available at http://assets.opencrs.com/rpts/R40528_20100419.pdf (last visited on Feb. 1, 2012).

65 See Report of the Monitoring Group on Somalia pursuant to Security Council Resolution 1811, supra note 8, at 30.

66 Roger Middleton, More than Just Pirates: Closing the Space for Somali Pirates through a Comprehensive Approach, in The International Response to Somali PiRacy: Challenges and Opportunities 16 (Bibi van Ginkel et al eds. 2010).

67 See Report of the Monitoring Group on Somalia and Eritrea Pursuant to Security Council Resolution 1916 (2010), S/2011/433, 33-34 (2011), available at http://reliefweb.int/sites/reliefweb.int/files/resources/Full_Report_1869.pdf (last visited on Feb. 1, 2012). 
interpreters would be often recruited from the outside networks and have often worked outside Somalia at some point in time, though they are frequently linked by clan affiliation. Negotiators, such as Ali Hassan Sharmarke and Looyaan Si' id Barte, work for two or more ships at the same time.68 Ransom payments are commonly delivered directly to the pirates on board. The ransom amounts have been increasing. In 2008, the average pirate ransom reached the range of USD $1.25-1.5$ million, which grew to USD $3 ? 4$ million in 2010.69 After a successful operation, the ransom is divided up on shore. The distribution formulas vary, but a typical distribution of ransom payments is as follows: $30 \%$ goes to the maritime militia; $10 \%$ goes to the ground militia; $10 \%$ goes to the local community; $20 \%$ goes to the financier; and $30 \%$ to the sponsor. Boya, a pirate group leader in Eyl, once claimed that $30 \%$ of the ransom payment went to the bribe. 70 The local economy has become dependent on successful hijackings and ransom payments for commercial vessels; a pirate safe haven has been constructed around this criminal enterprise. Murphy maintains that the influx of wealth is accepted by the community positively in terms of new business established to supply pirates with goods and services, including boat building, construction, restaurants, car dealing and money changing. ${ }^{71}$ Anjya Shortland argues that piracy has created employment and considerable multiplier effects on the Puntland economy,72 although Puntland authorities and others are highly critical of its analysis. ${ }^{73}$ It is not easy to determine the extent to which ransom payments contribute to developing the Puntland economy. Considering the GDP is estimated to be around USD 600 per capita, and an individual pirate can earn up to USD 10,000 per successful operation, there is no shortage of young men willing to become pirates in spite of the potential danger of death or imprisonment. 74

The grounding of piracy in Somalia is disputable. However, the most frequently cited reasons are illegal fishing and poverty. The first narrative is illegal fishing by foreign fishing vessels and the dumping of toxic waste into Somali territorial waters.

68 Id. at $35-36$

69 Jay Bahadur, The Pirates of Somalia: Inside Their Hidden World 140 (2011).

70 See Report of the Monitoring Group on Somalia pursuant to Security Council Resolution 1811, supra note 8, at 31.

71 Murphy, supra note 62, at 121-122.

72 Anjya Shortland, Treasure Mapped: Using Satellite Imagery to Track the Developmental Effects of Somali Piracy, in Africa Programme PAPER: AFP PP (2012), available at http://www.chathamhouse.org/sites/default/files/public/ Research/Africa/0112pp_shortland.pdf (last visited on Feb. 1, 2012).

73 See Somalia: "Piracy Research" Insult to Common Sense, Garowe Online (Jan. 15, 2012), available at http://www.garoweonline.com/artman2/publish/Somalia_27/Somalia_Piracy_Research_Insult_to_Common_Sense.sht $\mathrm{ml}$ (last visited on Jan. 15, 2012); Robert Pelton, Plunder, Politics, Presumption and Puntland, Somalia RePorT (Jan. 14, 2012), available at http://somaliareport.com/index.php/post/2530/Plunder_Politics_Presumption_and_Puntland. (last visited on Jan. 15, 2012).

74 Middleton, supra note 66, at 19. 
Somali pirates often claim that they are defending the country's fishing grounds and blocking toxic waste dumping. They tend to call themselves 'coast guards.' According to Ocean Training and Promotion (a Dutch NGO), more than 200 foreign vessels fished illegally along the Somali coast line from 1991 to 1999; they would earn about USD 300 million per annum. ${ }^{75}$ In accordance with a study by the University of British Columbia, foreign flagged vessels took half of the total fish catches in Somali waters.76 In 2005, the Food and Agriculture Organization ("FAO") estimated that about 700 foreign flagged trawlers were involved in illegal and unregulated fishing in and around Somali waters. 77 In addition, pirates or local people have alleged that toxic waste has been dumped illegally on land and in Somali waters for more than twenty years. Circumstantial evidence indicates illegal waste was dumped in the 1990s, although verification has proved difficult due to the security situation in Somalia.78

Although illegal fishing and toxic waste dumping are concerns of legitimacy, there is a kind of skepticism about these narratives. For example, illegal finishing had been a big problem in Somali waters even before the collapse of Barre's regime in 1991. Most ships attacked by pirates are not trawlers engaging in illegal fishing, but cargo ships and bulk carriers sailing to Yemeni or international waters. Stig Hansen shows that Somali pirates have targeted non-fishing vessels within the exclusive economic zone ("EEZ") off the coast of Somalia; only a few fishing ships have been attacked. ${ }^{79}$ Hansen, Middleton and others maintain that the illegal fishing argument might satisfy the pirates' psychological needs for self-justification, serving as propaganda to obtain support from the local community and political elites. 80

The second narrative is 'poverty.' It means that piracy is caused by economic deprivation (poverty) in Somalia. However, this argument has several problems. First, most piracy bases are not poorer than other regions in Somalia. Sanaag and Bari are estimated to be comparatively rich, Ngal is average and Mudug is slightly below average when it comes to income per family. Puntland is generally richer than the rest

75 Peter Lehr \& Hendrick Lehmann, Somalia- Pirate’s New Paradise, in Violence at Sea: PiRacy in the Age of Global TERRORISM 12-13 (Peter Lehr ed. 2007).

76 See Report of the Security-General on the Protection of Somali Natural Resources and Waters, S/2011/661, at 11 (October 25, 2011), available at http://unpos.unmissions.org/Portals/UNPOS/Repository\%20UNPOS/S-2011661\%20(250ct).pdf (last visited on Feb. 1, 2012).

77 See FAO Fishery Country Profile-The Somali Republic (January 2005), available at http://www.fao.org/fi/oldsite/ FCP/en/SOM/profile.htm (last visited on Jan. 12, 2012).

78 Supra note 76 , at $10-13$.

79 Stig Hansen, Debunking the Piracy Myth: How Illegal Fishing Really Interacts with Piracy in East Africa, 156 RoYAL UNITED SERVICES INSTituTE J. 26-31 (2011). http://www.rusi.org/publications/journal/ref:A4EE21AB627D0C (last visited on Feb. 1, 2012).

80 Id. at 30. See also Middleton, supra note 66, at 23-24. 
of Somalia. It is less likely that the pirate areas are poorer compared to other coastal areas, such as Togdheer, Lower Juba and parts of Shabelle. Second, the number of piracy incidents has drastically escalated from 2008 to 2012, although the poverty levels in Somalia remain the same. Third, poverty may be a factor driving individuals to join pirate groups, considering that each pirate is usually provided with financial resources. Hansen estimated the running costs of piracy are about USD 1000-2000 for a 15-foot pirate skiff costs and USD 100 a day for food, water and other supplies for the hostages and the pirate group. Poverty could be a reason why an individual decides to join a pirate group. However, it fails to explain geographical differences and the changes in the number of piracy incidents over time. 81

\section{Puntland and Piracy Enterprise}

Statistics shows there have been variations in the frequency of piracy incidents off the Somali coast. 82 In general, the number of incidents was around twenty per year between 2000 and 2004, but doubled in 2005 and decreased in 2006. However, piracy increased in 2007, and dramatically again in 2008 (Figure 1).83 The changes in the number of piracy incidents are strongly correlated to the political situation in Puntland.

Figure 1: Pirate Attacks in Somalia 2000-2011

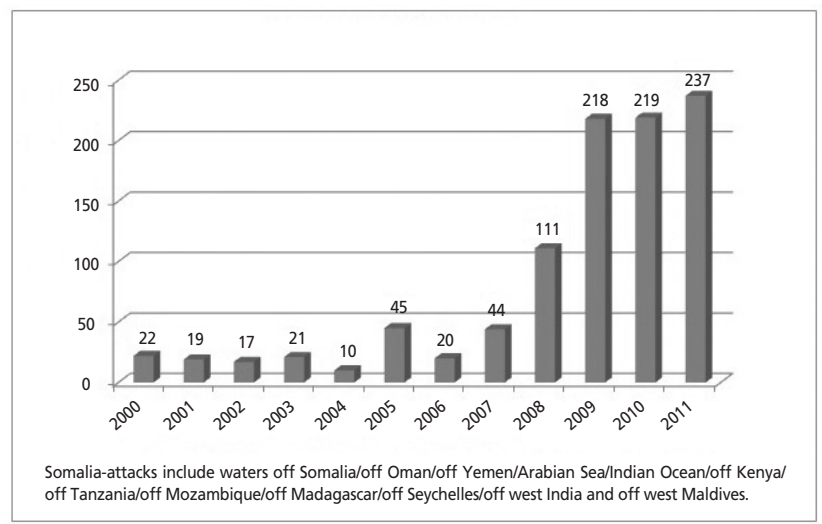

Source: IMB Annual Report on Act on Piracy and Armed Robbery against Ships, 2000-2011

81 Stig Hansen, Piracy in the Greater Gulf of Aden: Myths, Misconceptions and Remedies, 29 NIBR REPORT 14-15 (2009).

82 Id. at 19.

83 According to IMB reports, there were 22 Somali pirate attacks in 2000, 19 in 2001, 17 in 2002, 21 in 2003, 10 in 2004, 45 in 2005, 20 in 2006, 44 in 2007, 111 in 2008, 218 in 2009, 219 in 2010, and 237 in 2011. 
The Puntland state of Somalia emerged in 1998, after traditional clan leaders of the Darod held a meeting in Garowe and agreed to create a regional autonomous administration. The development of the political situation in Puntland can be divided into four phases. The first phase was the period between 1998 and 2001. Abdulaahi Yusuf Ahmed was elected as the first president by clan leaders for four years. Also, a regional parliament selected by clan leaders was established. New institutions, such as a tax and revenue collection system, were introduced; courts and prisons were (re)built in major towns. The new regime managed to maintain relative peace and consolidated its image as a functioning regional autonomous entity. At that time, Puntland was perceived as a successful model of the building block approach. 84

However, Puntland faced a serious political crisis in the second phase (2001-2005). President Yusuf refused to step down, even though his tenure expired on June 30, 2001. Clan elders appointed Yusuf Haji Nur as a caretaker president for elections in November 2010. Juma Ali Juma was elected the next president, but Yusuf did not accept the result and launched an attack against militia loyal to Juma. On the basis of financial and military support from Ethiopia, Yusuf's forces gained control of several towns. Yusuf proclaimed himself president and ordered his elite special security forces, the Darawish, and the Puntland Intelligence Service to crack down on dissidents. The freedom of the press was thus severely restricted and politics based on consensus across clans and sub-clans waned. Yusuf's regime was founded on a narrow power basisparticularly on his affiliation with the Omar Mohamoud sub-clan-while nepotism, cronyism and corruption were widespread in every aspect of life in Puntland. As a consequence, public support for the regime declined, and internal fighting between subclans intensified. Political and economic turmoil continued in Puntland until Yusuf left Puntland to become president of the TFG in 2004.85

The third phase started in January 2005 when Adde Muse Moquor became president. Under his regime, piracy continuously increased, while Puntland's political and economic situation seriously deteriorated. Corruption penetrated deeply into every tier of the government's structure. This had a devastating impact on Puntland's economy. Traders had to bribe officials to obtain licenses to import food, fuel and consumer goods. Firms having a strong connection to government officials would get fishing licenses and mineral exploration rights. Livestock export licenses were sold to those who could pay the largest bribes or who had powerful connections with the authorities. As a result, the price of food and other basic goods rose, and malnutrition

\footnotetext{
84 International Crisis Group, Somalia: The Trouble with Puntland, 64 Africa BRIEFING 3-5 (Aug. 12, 2009), available at http://www.somaliawatch.org/archivejun09/090815601.pdf 3-5 (last visited on Feb. 1, 2012).

85 Id. at 5-6.
} 
and poverty increased. The government proved incompetent in solving economic problems; inadequate economic policies created turmoil in the currency and escalated hyperinflation. Due to such bad economic policies, along with a severe drought, Puntland faced a serious humanitarian crisis. 86

It is often argued that the emergence of piracy off the Somali coast is associated with the establishment of the coast guard during Yusuf's regime. In 1999, President Yusuf contracted the Hart Nimrod to establish a maritime security force to patrol the EEZ along Puntland. The Hart Nimrod used the M/V Celtic Horizon and appointed a number of security consultants to train between seventy and eighty Puntlander coast guard members. Crew members of the Hart and coast guard members policed areas to arrest or collect fines from foreign trawlers engaged in illegal fishing. The fines from the foreign trawlers, sales, or fishing licenses were expected to be major sources of revenue for Puntland authorities, though this proved to be untrue. 87 The coast guard venture was caught up in the conflict between Yusuf and his political enemies in 2001. This affected the coast guards themselves, who were split into two groups, each half supporting different factions. 88 Moreover, the licensing scheme caused further friction between the Hart group and Yusuf's regime. In 2002, the Hart finally ended its operations in Puntland. As several coast guard members reportedly trained by the Hart started new careers as pirates, piracy became more systematized and better coordinated. During Muse's tenure, illegal activities such as illicit arms trade, human trafficking, forgery of currency and kidnapping thrived in Puntland, as well as piracy. 89

Martin Murphy describes seven major factors that encourage piracy: (1) legal and jurisdictional opportunities; (2) favorable geography; (3) conflict and disorder; (4) under-funded law enforcement and inadequate security; (5) a permissive political environment; (6) cultural acceptability and maritime tradition; and (7) reward. Piracy occurs for one overriding reason: 'opportunity.' 90 Puntland shares all these factors, except for the "cultural acceptability and maritime tradition." In geopolitical perspectives, especially, Puntland's location and its relative stability have allowed piracy to flourish in Puntland. Puntland is located at the intersection of the Indian Ocean and the Gulf of Aden, one of the most important trade routes between Asia, the Middle East, and Europe. Approximately 16,000 ships, or $12 \%$ of the global maritime trade transits through the Gulf of Aden each year.91 In addition, Puntland's isolation

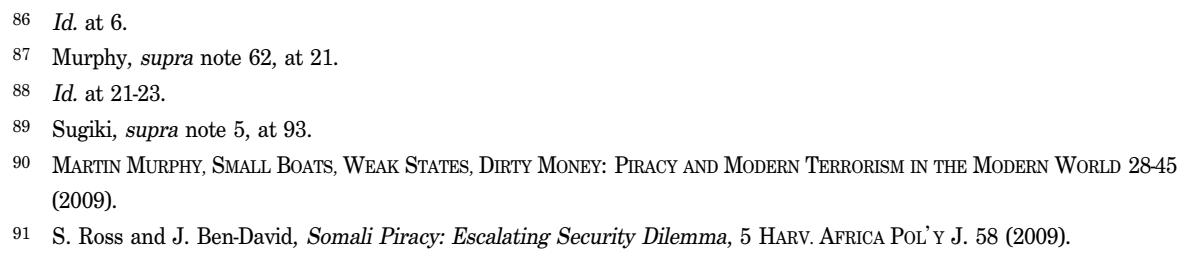


from conflicts and semi-lawless situations made the region an ideal place for pirates. There is substantial empirical evidence that the frequency of pirate attacks is related to political stability. In addition, environmental crises, such as the severe drought from 2002 to 2004 and the tsunami in December 2004, as well as a failing economy mirrored by the decline of political institutions contributed to the increase in piracy. Also, a kind of criminal syndicate has developed, encompassing not only pirates, bankers, investors, accountants, bakers, negotiators, lawyers, and caretakers, but also local leaders and security forces. Due to the profit from piracy, and the lack of alternative employment opportunities, government officials, police officers and local inhabitants have become engaged in piracy. ${ }^{92}$

\section{State-Building and the Response to Somali Piracy}

\section{A. The Top-Down Approach: Strengthening Security Sector Reform in the TFG and the Effect on Piracy}

As discussed above, the state-building method known as the 'top-down approach' focuses on strengthening the central government's capacity to counter piracy by assisting the TFG's security forces and justice system.

Following the Dibouti peace process, the TFP was enlarged to include members of the ARS-Djibouti and the members of parliament elected Sheikh Sharif president in 2008. The current TFG security forces are nominally composed of members of the former TFG military, police and intelligence forces, as well as members of the previous ARC-Djibouti. One of the major challenges of the current TFG is to construct a unified command and exert control and discipline over these disparate security forces and militias. 93 The TFG security forces are a military unit challenged by Hizbul Islam and Al-Shabaab, whose commanders now control most of southern and central Somalia. Somalia has no strong national armed forces or police that can enforce the government's authority and protect its people. Until late 2011, the writ of the TFG has been restricted to a few key areas in Mogadishu protected by the AMISOM. ${ }^{44}$

See Hansen, supra note 81, at 39-41; Murphy, supra note 60, at 115-117; Report of the Monitoring Group on Somalia pursuant to Security Council Resolution 1811, supra note 8, at 31-32; Report of the Monitoring Group on Somalia pursuant to Security Council Resolution 1853(2008), S/2010/91, at 39 (Mar. 10, 2010), available at http://somalitalkradio.com/2010/mar/un_report_somalia.pdf (last visited on Feb. 1, 2012).

93 Supra note 6, at 15.

94 Id. at 17-18. It is reported that the TFG formed a new administration in the Hiraan region of central Somalia in March
} 
While dispatching naval forces to impede piracy off the Somali coast, the international community has come to realize the need to tackle the root causes of maritime piracy, which lie in the instability ashore. Thus, the international community, especially the EU, has begun to assist Somalia with the security sector reforms aimed at providing basic security and discouraging piracy and other crimes. Since 2009, the international community has increased military aid to the TFG security forces. The EU is Somalia's largest donor; the EU's Special Support Program for 2008?2013 has a budget of Euro 215.4 million. 95 Other donors include the U.S., the U.K., Norway, Denmark, Japan, Canada, the Netherlands, as well as the World Bank and the League of Arab States. 96

With regard to a land-based initiative to combat the causes of piracy, the US provided about 40 tons of arms and ammunition to the TFG forces and USD 2 million financial assistance through the AMISOM. France trained a battalion of 510 soldiers at a French military base in Dijibuti in 2009; Uganda, Djibouti and Sudan also trained TFG forces in 2009. Between 2002 and 2010, the UN Development Program ("UNDP") conducted a law enforcement project that supported training for the TFG police force. ${ }^{97}$ The training was carried out in Puntland, Djibouti, Kenya, Uganda, and Ethiopia. In January 2011, the AMISOM took over much of the police training. 98 In September 2009, the Philippines offered training to the Somali coast guard.99 Among the various operations, the European Union Training Mission for Somalia ("EUTM"), which started in April 2010, is regarded as superior in quality. In Bihanga, the Uganda People's Defense Force ("UPDF") provides basic training for soldiers. 100

However, there are four major problems with this mission, in spite of the quality of the training. First, the TFG forces are not regarded as a legitimate national security force. The selection process for trainees does not represent various Somali clans in a fair

2012. See Aweys Cadde, TFG Forms New Administration in Hiiraan, Somalia Report (Mar. 11, 2012), available at http://www.somaliareport.com/index.php/post/3054 (last visited on Feb. 1, 2012).

95 European Commission Development and Cooperation-EuropeAid, EC Assistance to Somalia (January 2009), available at http://ec.europa.eu/europeaid/where/acp/regional-cooperation/peace/documents/dev_ec_assistance_somalia.pdf (last visited on Dec. 12, 2011).

96 UNDP Somalia, Donors and Expenditure, available at http://www.so.undp.org/index.php/Donors-and-partners.html (last visited on Dec. 12, 2011).

97 UNDP in Somalia, Civilian Police, available at http://www.so.undp.org/index.php/1Law-Enforcement.html (last visited on Jan. 5, 2012).

98 AMISOM Launches Training Course for Somali Police Force Commanders, available at http://au.int/en/sites/ default/files/AMISOM\%20Press\%20Release\%2018-01-2012.pdf (last visited April 25, 2012)..

99 See Philippines Offers Training for Somali Coast Guard, GuARDiAn (Sept. 1, 2009), available at http://www.guardian.co.uk/world/feedarticle/8685387?FORM=ZZNR3 (last visited on Dec. 12, 2011).

100 See EUTM Somalia - European Union Military Mission to Contribute to the Training of Somali Security Forces, available at http://www.consilium.europa.eu/eeas/security-defence/eu-operations/eu-somalia-training-mission (last visited on Jan. 20, 2012). 
manner, but favors instead certain clans such as the Abgal. Because the trainee candidates are selected by the TFG and the final phase of training is carried out in Mogadishu, self-autonomous regional governments or political groups such as the Ahlu Sunna Waljama' a ("ASWJ") have refused to dispatch their forces for training. Thus, Somalis suspect the EUTM training will build a partisan force loyal to President Sharif rather than a cross-clan national army.101 Second, the structural reform of the security sector is not progressing positively, due to widespread corruption and powerfully vested interests. There has been a great deal of resistance to attempts to create an effective chain of command, rational military formations and even a credible roster. ${ }^{102}$ Third, the sustainability of the TFG's security forces is questionable. The TFG's security forces rely entirely on external assistance, including military training, the payment of salaries and the distribution of equipment. Despite fears that trained forces would defect to join Al-Shabaab, the AMISOM reported that the defection rate was around $10 \% .103$ This figure is relatively lower than in other conflict areas, such as Afghanistan.104 However, there is no guarantee that trained soldiers will remain loyal to the TFG or a new central government. This, to a certain extent, depends on regular payments to the troops. According to media reports, pay is infrequent and often delayed, despite financial assistance from donors. 105 Al-Shabaab has been weakened by the famine, as the leadership disagreed with each other whether to accept international aid.106 Further military intervention by the Kenya Defence Force ("KDF") and Ethiopia has also forced Al-Shabaab to withdraw its troops from a part of Gedo, Lower Juba, as well as Beledweyen.107 Despite the fact that the AMISOM, the TFG forces and the TFG's allied militias have expanded the 'liberated areas,' including Mogadishu, Hiran, Galgudud and Mudug, these areas still remain unstable. It is highly unlikely that the TFG or a new

101 Supra note 5, at 15-16. President Sharif is from the Abgal (sub-clan of Hawiye). As the selection process favors certain clans, in particular the Abgal, Somali cast doubt that Sharif is building a partisan force.

102 Id.

103 European Security Review, Briefing 8: October 2011 (EUTM Somalia, April 7, 2010 to July 2011) available at http://www.isis-europe.eu/sites/default/files/programmes-downloads/Oct2011EUTM.pdf (last visited on Sept. 15, 2011).

104 Id.

105 See e.g. Alinoor Moulid, Somali Forces Finally Received Regular Wages, Somalia RePORT (Mar. 18, 2011) available at http://www.somaliareport.com/index.php/post/321/Somali_Forces_Finally_Receiving_Regular_Wages (last visited on Jan. 2, 2012); Mohamed Merdige, TFG Soldiers Paid for the Frist Time Since July, Somalia RePoRT (November 16, 2011) available at http://www.somaliareport.com/index.php/post/2047 (last visited on Jan. 2, 2012)

106 Leela Jacinto, Will the Famine Weaken Somalia's Al-Shabaab Militants?, FrANCE 24 (July 29, 2011), available at http://www.france24.com/en/20110729-somalia-al-shabaab-famine-weakens-divides-qaeda-linked-militants (last visited on Dec. 12, 2011); The Fund for Peace, Al-Shabaab and the Somalia Food Crisis, CF-11-05-CA, Briefing (August 2011) available at http://www.fundforpeace.org/global/library/cf-11-05-tc-briefing-alshabaab-1108e.pdf (all last visited on Nov. 3, 2011).

107 Rashid Abdi, Is Somali's Al-Shabab on the Back Foot?, BBC (Jan. 12, 2012) available at http://www.bbc.co.uk/ news/world-africa-16510716 (last visited on Jan. 13, 2012). 
central government could gain control of pirate hotspots in Puntland in the near future. Rather, any such attempt to exert authority over Puntland would only contribute to weakening the one entity in Somalia that has so far managed to sustain relative order and stability.

\section{B. The Bottom-Up Approach: Puntland, Security Sectors and Counter-Piracy}

When Abdirahman Mohamed Farole was inaugurated as president in January 2009, he declared war against piracy. He claimed that anti-piracy policies would incorporate police action with community and religious advocacy. 108 Muslim scholars, such as Sheikh Abdulkadir Nur Farah, and elders from Bossaso and Garowe have cooperated with the government and embarked on a campaign to persuade pirates to quit. As a result, several pirates have decided to quit their business. In particular, Abshir Boyah, an influential pirate leader, announced in a public meeting in May 2009 that he would retire from piracy.109 As for the crackdown on pirate groups, since April 2009, security forces have attacked several areas, including Eyl and Bargaal, and arrested pirates. They were brought to justice and sentenced to prison terms ranging from three to twenty years. In May 2009, Puntland's government authorized the confiscation of property belonging to those connected to acts of piracy. Puntland authorities reported that, over the past two years, more than 350 pirates were arrested and pirate groups based in several coastal towns in Puntland were wiped out.110

Puntland also signed an agreement with Saracen International to train 1,050 marine forces in October 2010.111 From October 2, 2010, to February 17, 2011, Saracen trained 470 soldiers and drivers enlisted by Puntland's government and the Puntland

108 See Muslim Scholar Speaks about Reforming Pirates, Garowe Online (May 26, 200), available at http://www.garoweonline.com/artman2/publish/Somalia_27/Somalia_Muslim_scholar_speaks_about_reforming_pirat es_printer.shtml (last visited on Dec. 21, 2011).

109 However, Boyha returned to piracy and was arrested by Puntland's security forces in May 2010. See Somalia: Puntland Forces Arrest Wanted Pirates in Garowe, Garowe Online (May 18, 2010) available at http://allafrica.com/ stories/201005180912.htm (last visited on Nov. 14, 2011).

110 See Somalia: First Batch of 170 Puntland Marines Complete Navy Training, Garowe Online (November 30, 2010) available at http://www.garoweonline.com/artman2/publish/Somalia_27/Somalia_First_batch_of_170_Puntland_ marines_complete_naval_training.shtml (last visited on Nov. 24, 2011).

111 Saracen International is a private military company that provides a comprehensive program to enhance marine forces' capacity to fight the pirates and regain control of illegal fishing in the Puntland territorial waters. See Somalia: Puntland Signed An Agreement with Saracen Company to Train Its Marine Forces, Garowe Online (November 18, 2010), available at http://www.garoweonline.com/artman2/publish/Press_Releases_32/ Somalia_Puntland_signed_an_agreement_with_Sarecen_Company_to_train_its_Marine_Forces.shtml (last visited on Mar. 25, 2011). 
Development Group. However, the United States and the UN were worried about the contract between Puntland and Saracen International due to a potential breach of the arms embargo under the UN Security Council Resolution.112 Eventually, Puntland suspended the contract in February 2011.113

Initially, there was little international assistance to Puntland to enhance its capacity to decrease piracy. However, given the limited capacity of the TFG and various recommendations by those engaged in the piracy issues in Somalia, the international community has begun to strengthen its working relationship with Puntland. For example, as part of the UNDP's Rule of Law program, more than sixty Puntland policemen were trained. The NATO has conducted regular meetings with Puntland coast guards for human intelligence gathering, capacity building, and counter-piracy cooperation. 114 In December 2011, the EU Council also approved a new common security and defense policy mission to provide training for a coastal police force and training and protection for judges in Puntland.115

Such positive developments, notwithstanding, concerns remain about providing support to the Puntland authorities. The international community is worried that highlevel government figures are colluding with pirate groups. The UN monitoring group reported that senior Puntland officials, including President Farole and members of his cabinet, have received proceeds from piracy and/or kidnapping. 116 The president, however, denied the allegations and condemned the monitoring group's report as 'politically motivated.' 117 So far, the Farole regime's attempt to combat piracy has met with mixed results. On the one hand, Puntland security forces arrested more than 290 pirates, including a famous leader, Abshir Sbillahi Boyah.118 In January 2011, he was sentenced to five years in prison in Bossaso with a fine of 50 million Somali shillings

112 See Report of Security Council Committee Pursuant to Resolutions 751 (1992) and 1907 (2009) Concerning Somalia and Eritrea, available at http://www.un.org/sc/committees/751 (last visited on Feb. 1, 2012).

113 See Somalia: Puntland Government suspends Saracen International's Contract, RBC Radio, available at http://www.raxanreeb.com/?p=87583 (last visited on Mar. 25, 2011).

114 See NATO Commander Meets Puntland Coast Guard, Allied Command Operation, available at http://www.aco.nato.int/page272205428.aspx (last visited on Jan. 5, 2012).

115 See Fight Against Piracy: Council Launches EU Action to Strengthen Maritime Capacities in the Horn of Africa, Council of the Europe Union (Dec. 12, 2011), 18321/1/11 REV1, PRESSE480, available at http://www.consilium.europa.eu/ uedocs/cms_data/docs/pressdata/en/trans/126783.pdf (last visited on Feb. 1, 2012).

116 See Report of the Monitoring Group on Somalia pursuant to Security Council Resolution 1853, supra note 8, at 39.

117 See Somalia: Puntland's Leader Says UN Report Is "Politically Motivated," Garowe Online (May 22, 2010), available at http://www.garoweonline.com/artman2/publish/Somalia_27/Somalia_Puntland_s_leader_says_UN_report_is_ politically_motivated_printer.shtml (last visited on Jan. 13, 2012).

118 According to the UNODC's report of October 12, 290 pirates were arrested and about 240 convicted. See UNODC, Counter-Piracy Programme: Support to the Trial and Related Treatment of Piracy Suspect, Issue 7, 11 (2011), available at http://www.unodc.org/documents/Piracy/UNODC_Brochure_Issue_7_WV.pdf (last visited on Jan. 4, 2012). 
(USD 30,000). On the other hand, other well-known Puntland pirate leaders and negotiators, such as Mohamed Abdi Garaad, Abdullhi Ahmed Haji Farah (Abdi Yare), Mohamed Saaili Shibin (Ali Jama), Abdulhadir Musse Hirsi Nur (Computer), 'Bakelye' and Loyaan Si' id Barte (Loyan), continue to visit Puntland or to operate there without impediment.119 Thus, it is hard to figure out to what extent Puntland authorities are infiltrated by pirates, and the degree to which authorities are committed to resolving piracy issues. Any approach focusing on Puntland must start from the fact that some officials might be paid by the pirates. This means that institution-building is not possible, but strong negotiation and support, along with external and international pressure, are necessary to build functional local institutions. Piracy is not fully embedded in Somali society. Local leaders, clan elders and religious leaders do not condone piracy. Advocacy campaigns or mass demonstrations against piracy have been organized in several places.120 The mayor of Bender Beyla (one of the main pirate bases in Puntland), Said Aden held a mass protest attended by hundreds of residents against piracy in April 2011.121 In March 2011, the Anti-Piracy Committee of Bar-gal demanded pirates leave the area. Then, there was a clash between local residents and the pirate group. 122 Such attempts do not always end in success. In some cases, however, pirates were forced to leave under strong pressure from local communities. At the end of January 2011, pirates left their base at Garacad after local elders and the Puntland government requested they leave.123 In addition, in December 2011, a nine-year old boy held hostage was released without ransom after local elders and the Galmudug authorities negotiated with the pirates. 124

\section{The Mediated State Approach to State-Building and Counter- Piracy Measures}

Hansen recommends seven principles for evaluating coercive strategies to block piracy: (1) sustainability; (2) relevance; (3) local ownership; (4) international coordination; (5) do no harm; (6) cost effectiveness; and (7) positive spill-over effects.125 Considering the

\footnotetext{
119 Supra note 67, at 39-40.

120 Yahya Mohamed, Anti-Piracy Demonstrations in Puntland, Somalia RePoRT (Mar. 26, 2011) , available at http://www. somaliareport.com/index.php/post/298/Anti-Piracy_Demonstrations_in_Puntland (last visited on Jan. 12, 2012).

121 See Protest Against Pirates in Bender Beyla, Somalia RePoRT (Apr. 17, 2011), available at http://www.somaliareport. com/index.php/post/555/Protests_Against_Pirates_in_Bender_Beyla (last visited on Jan. 17, 2012).

122 See Pirates and Locals Clash in Bar-Gal, Somalia RePORT (Mar. 19, 2011), available at http://www.somaliareport. com/index.php/post/339 (last visited on Jan. 12, 2012).

123 Supra note 67 , at 38 .

124 See Somali Pirates Release Abducted Children Unharmed, Somalia RePORT (Dec. 17, 2011), available at http://www. somaliareport.com/index.php/post/2342 (last visited on Jan. 15, 2012).

125 Hansen, supra note 81 , at $42-44$.
} 
situations of security forces in the TFG and Puntland, strengthening local institutions is more sustainable, relevant and cost-effective for tackling piracy. Local ownership would be also secured.

In fact, some donors have already begun working with local administrations of Somaliland and Puntland, although they still regard the TFG as the legitimate central government. In September 2010, U.S. Assistant Secretary of State for Africa Affairs Johnnie Carson announced a dual track policy that would engage both the Somaliland and Puntland administrations, and establish regional political authorities. The EU also suggested it would increase its financial assistance to central, regional and local administrations. In December 2011, the EU Council approved the start of a new assistance program to provide training to a coastal police force, as well as training and protection for judges in Puntland, Somaliland and Galmudug. ${ }^{126}$ Further, after long rejecting recognition of the administrations' mere existence, the AU's Peace and Security Council requested that the chairperson of its Commission, Jean Ping, "broaden consultations with Somaliland and Puntland as part of the overall efforts to promote stability and further peace and reconciliation in Somalia as a whole." 127

While the decision to divert aid to local authorities is less controversial, the continuous attempts to create a unified national army are still contentious. Since almost all local administrations have their own paramilitary units, it is implausible that a unified army would be formed under a single command. As argued in previous sections, since Somali society relies heavily on the clan system, many clans or local administrations would reject the idea that opens up the possibility of a national army dominated by a single clan and used to enforce its rule. Rather, given all the conditions and available options in Somalia, it is crucial to consider how to bring the regional security forces or militias under the control of the federal Somali State. The meditated state model proposed by Menkhaus, Bøås and Rotwitt suggests, e.g., a power-sharing arrangement between the central government and strong regional governments. While the regional governments perform most ordinary governmental tasks, including provision of local security, the central government performs a limited number of specific core tasks. 128 Alternatively, as the International Crisis Group points out, it may be possible to construct a national army based on clan and/or regional lines. In the U.K.,

126 EU, Common Security and Defence Policy: Regional Maritime Capacity Building for the Horn of Africa and the Western Indian Ocean, available at http://www.consilium.europa.eu/media/1362586/001_fact_sheet.pdf llast visited on Jan. 5, 2012).

127 Africa Union Peace and Security Council, Communique of the 245th Meeting 3 (2010), available at http://www.ausitroom-psd.org/Documents/PSC2010/245th/Communique/communiqueSomaliaen.pdf (last visited on Jan. 7, 2012).

128 Bøås \& Rotwitt, supra note 52, at 2 . 
many units are recruited from specific regions and have their own infantry regiments, while, in the U.S., national guard units are recruited from and commanded by a single State. 129

Unlike Somaliland, Puntland declared its intention to be an independent and integral part of the federal Somali State. The Somali Transitional Charter, adopted in 2004, also provides: "The Transnational Federal Government of the Somali Republic shall have a decentralized system of administration based on federalism" 130 The final draft of the Somali constitution contains the principle of federalism.

The TFG and Puntland signed the Galkayo accord and the MOU on security cooperation in April 2010. In these accords, they agreed to strengthen law and order both on- and off-shore, and to establish a Somali navy to fight piracy (with its headquarters in Puntland). 131 In January 2010, the TFG, Puntland and Somaliland joined the Kampala process intended to promote internal coordination, information-generation and sharing under the auspices of the Somali Contact Group on Counter-Piracy. Although Puntland had a falling out with the TFG in January 2011,132 a rapprochement was reached between the two sides after they signed the MOU to implement the Galkayo accord on August 23, 2009. The MOU on security cooperation was signed by the TFG and Puntland on April 12, 2010. It discusses cooperation in strengthening security to fight terrorism and piracy, as well as the creation of a federal charter.133

However, there are certain ambiguities about the future relationship between Puntland and the central government in a federal Somali State. The main challenges are as follows: (1) how to arrange a political structure based on decentralization and federalism?; (2) how to determine the administrative units and their boundaries?; (3) how much autonomy should regional administrations be given?; and (4) is there a possibility that a region, such as Somaliland, might secede from Somalia? In general, there are four possibilities: (1) a confederation (a union of separate but equal states); (2) a federal system (with three ways of organizing federal-provincial relations); (3) a

129 Supra note 6, at 22 .

130 See Somali Transitional Charter: Transitional Federal Charter for the Somali Republic, Chapter 4, Article 11 (1), REFWORLD, available at http://www.unhcr.org/refworld/docid/4795c2d22.html (last visited on Dec. 15, 2011).

131 See Somalia: Puntland, TFG Sign Deal to Horminse Galkayo Accord, Garowe Online (April 2010), available at http://www.garoweonline.com/artman2/publish/Somalia_27/Somalia_Puntland_TFG_sign_deal_to_horminse_Galkay o_accord.shtml (last visited on Dec. 20, 2011).

132 See Puntland's New Position towards the TFG of Somalia, Garowe Online (Jan. 16, 2011), available at http://www.garoweonline.com/artman2/publish/Press_Releases_32/Puntland_s_New_Position_Towards_the_TFG_of _Somalia.shtml (last visited on Dec. 20, 2011).

133 See Ahmed Abdi, TFG-Puntland Sign Memorandum of Understanding (August 29, 2011), available at http://somaliareport.com/index.php/post/1479/TFG-Puntland_Sign_Memorandum_of_Understanding (last visited on Feb. 1, 2012). 
decentralized unitary State with guarantees of regional or local autonomy; and (4) a consociation (a non-territorial option). In September 2011, representatives from the TFG, the semi-autonomous regional governments of Puntland and Galmudug, political groups such as Ahlu Shunna Wal Jama and numerous civil society organizations attended a UN-backed meeting on ending the Somali transitional period. They agreed on a road map that identifies priority measures to be implemented before the TFG's mandate expires in August 2012. The road map consists of four pillars; security, constitution and parliament reform, good governance, and political outreach and reconciliation. When the first national constitutional conference was held in Garowe from December 21 to 23 in 2011, delegates agreed that the 4.5 formula of representation would not be the basis for power sharing in the future, after the next election in 2012. This is a result of negotiations based on the Puntland initiative for region-based constituencies - rather than those organized by clan - in order to select members of parliament. Under this system, Puntland would gain a greater number of members of parliament. 134 At the moment, it is quite uncertain how the central government will devolve power to local administrations or even whether the new political structure will in fact emerge after the end of the transitional period. It remains to be seen how the model of the mediated state will be incorporated in Somalia.

\section{Conclusion}

This paper considers counter-piracy strategies in the context of state-building in Somalia. Piracy does not only take place at sea, but it also depends on what happens on land. A widespread agreement is emerging among academics and naval communities that any attempt to solve piracy should be started from the land in Somalia.135 This is because the unstable political situation on land is largely responsible for the piracy on the water. A fundamental solution to piracy will not be realized without a functional government, an effective policing and judicial system and a solution to the problems related to the reconstruction of the State in Somalia.

As past practices illustrate, there are few successful state-building cases in spite of

134 See Somalia Leaders Sign Garowe Principles at Constitutional Conference, Garowe Online (Dec. 24, 2011), available at http://www.garoweonline.com/artman2/publish/Somalia_27/Somalia_leaders_sign_Garowe_Principles_at_ Constitutional_Conference.shtml (last visited on Dec. 26, 2011).

135 See e.g. Shortland, supra note 72; Hansen, supra note 79; Ken Menkhaus, Dangerous Waters, 51 SuRvival: GLOBAL Politics \& Strategy (2009); W. G. Dunlop, Anti-Piracy Efforts Treat Symptom, Not Disease: Navy Chiefs, AFP (May 13, 2010), available at http://www.google.com/hostednews/afp/article/ALeqM5jk8JeTNHcH1N_4ZcMf5Oa66eUKVg. 
various efforts to rebuild failed states in post-conflict countries. This failure is ultimately due to the fact that the international community has focused on the institutional aspects of state-building under the Western model of statehood. Little attention has been paid to the questions of legitimacy, which is essential to a functional government. For this reason, this paper examines the attempts at state-building at the national and regional levels by using the concept of 'negotiating statehood' as a guiding framework. In Somalia, negotiations at the national level have not been successful. At the regional level, however, alternative regional governance has emerged as a consequence of negotiations between clan elders and leading regional politicians. As in the case of Puntland, this localization of government authority has managed to sustain relative order and stability. Thus, the "mediated state approach," which upholds decentralization and federalism, is the most appropriate approach to rebuilding the State in Somalia. In this framework, the central government relies on a partnership with local institutions that provide basic social services, justice and conflict management.

As far as counter-piracy policies are concerned, it would be more realistic to strengthen the capacity of the regional governance and security forces in Puntland, where pirates are actively working. In the face of internal and external pressure, since 2010, Puntland authorities have implemented a firm policy against piracy. During the course of a year, pirate groups moved from the pirate stronghold of Eyle to Garacad in the northern Mudug region. 136 The international community has begun to provide more assistance to Puntland and other regional governments.

However, the support given to Puntland and other regional authorities is not free from potential side effects. As shown in this paper, piracy and piracy-related economic activities have dominated the local economy in Puntland, based on mutual profitsharing. The UN monitoring Commission reported that even high-ranking government officials - including President Farole and his cabinet members - may have been bribed by pirate groups, although the president and his cabinet denied the allegations. Nevertheless, when all options are considered, the best approach is to increase local capacity to deal with piracy. This does not imply that we should close our eyes to the corruption or misconduct of local authorities, nor should we condone piracy. Rather, we should make sure that all assistances go directly to Puntland's security forces to investigate piracy. President Farole once claimed that piracy may be considered the foremost issue from a global point of view. In a different sense, it is only a tiny part of all of the problems prompted by the collapse of the Somali State.137 Piracy off the Somali coast is a symptom of the international community's flawed approach to state-building

136 Supra note 67 , at 39 .

137 Brian Hesse, Where Somalia Works, in Somalia: State Collapse, Terrorism and Piracy 111 (Brian Hesse ed. 2011 ). 
in Somalia, though the dramatic increase in the number of piracies between 2005 and 2008 is directly associated with Puntland's unstable political and economic situation. Thus, more holistic strategies are required to tackle the root cause by properly addressing how pirates can operate from safe havens on land and why individuals decide to join pirate groups. This will ultimately be achieved mainly through homegrown initiatives, instead of external military intervention or political interference. 